\title{
Effect of the Molten Metal Stream's Shape on Particle Size Distribution of Water Atomized Metal Powder
}

\author{
Suchart Yenwiset ${ }^{\mathrm{a}}$ and Tawichart Yenwiset ${ }^{\mathrm{b}, *}$ \\ Department of Industrial Education, Faculty of Industrial Education and Technology, Rajamangala \\ University of Technology Srivijaya, Songkhla, Thailand \\ E-mail: asuchart_yen@hotmail.com, bytawichart@hotmail.com (Corresponding author)
}

\begin{abstract}
The current knowledge indicated that water pressure, molten metal temperature, water flow rate and water jet configuration are very important factors which affect on the particle size distribution and shapes of atomized powder. This study aimed to investigate whether the shape of molten affects the particle size of atomized powder. The experiments were the production of copper powder with the fixed atomization process conditions, but varied the shape of molten metal by using two different shapes of tundish nozzle's orifice to make the round and rectangular cross section of molten metal stream. There were three sizes for each orifice shape to determine the rate of production (metal flow rate) at $13 \mathrm{~kg} / \mathrm{min}, 19 \mathrm{~kg} / \mathrm{min}$ and $26 \mathrm{~kg} / \mathrm{min}$. The results showed that at the same flow rate of molten metal the production of flat metal stream from rectangular orifice made higher yield of finer particle, smaller median size (D50) and narrower range of size distribution than the production with the round cross section orifice for every production rates.
\end{abstract}

Keywords: Metal powder, water atomization, particle size distribution, tundish.

ENGINEERING JOURNAL Volume 20 Issue 1

Received 28 February 2015

Accepted 4 August 2015

Published 29 January 2016

Online at http://www.engj.org/

DOI:10.4186/ej.2016.20.1.187 


\section{Introduction}

The metal powder used in the manufacturing process must have appropriate properties such as size, shape, and size distribution. Particle size is one of the most important properties to be considered, for using finer resolution powder enhances the accuracy of the work piece [1].

Atomization is one of the leading forerunners among the most promising and economic techniques for the fabrication of powders. the commonly applied mechanism for atomization involves the disintegration of liquid into a fine spray of droplets by high-velocity fluids [2].

Powder production, using an atomization process, has been being widely investigated and applied in industry [3], due to its advantages including high capacity, high flexibility for both elemental and pre-alloyed powder production and capability for rapidly solidified metal powder production. The rapidly solidified metal powders usually exhibit superior properties caused by fine microstructure, chemical homogeneity, extended solid solution and metastable phase formation. Therefore, metal parts produced from the rapidly solidified metal powders show superior mechanical properties.

In principle, when the metal melt is caused unstable by any forces it will be broken into forms of smaller pieces or droplets. Melt disintegration mechanism is shown in Fig.1 [4].
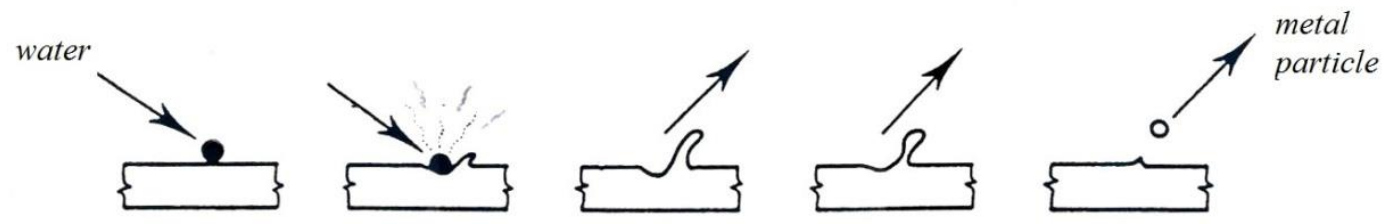

Fig. 1. The schematic steps involved in the "scrape" mechanism of water atomization [4].

Atomization begins with melting of metal. The liquid metal flows through a sized orifice from a tundish nozzle. Liquid flow is impinged by a high velocity stream of water. This breaks the liquid stream into particles that solidify rapidly. Particle size and shape are greatly influenced by the atomizing medium, pressure, and flow rate $[5,6]$.

For commercial practice of production of copper powder, liquid copper is superheated to about 1,150 to $1,200{ }^{\circ} \mathrm{C}$, utilizing flow rates of $27 \mathrm{~kg} / \mathrm{min}$ or more. Generally, to produce -100 mesh $(-149$ micron) copper powder, water pressure of 10 to $14 \mathrm{MPa}$ (1,500 to 2,000 psi) is used. Atomization may be conducted in an air or inert (nitrogen) environment [7]. The typical yield of producing -325 mesh (-44 micron) powder with atomization method is from 25 to 80 percent [8].

High Pressure water atomization can provide fine powder. With increasing atomization water pressure, the particle size tends to become finer and particle size distribution also tends to become broader [9].

German (2001) reported the result of steel powder producing using 1.7 MPa water pressure and the obtained average particle size is $117 \mu \mathrm{m}$ stating that if the water pressure is increased to $13.8 \mathrm{MPa}$, the average particle size decreases to $42 \mu \mathrm{m}$ [10].

Seki et al. (1990) found that to produce finer particle resolution of $10 \mu \mathrm{m}$, the process must operate with higher water pressure called High-Pressure Water Atomization (HPWA) which required very high water pressure up to $70 \mathrm{MPa}$. They also presented the relationship between the average metal particle diameter and the atomization pressure for two types of water atomization process as the following equations [11]:

$$
\begin{gathered}
D=68 P^{-0.56} \text { for } \mathrm{V} \text {-jet water nozzle } \\
D=114 P^{-0.58} \text { for cone water nozzle }
\end{gathered}
$$

where $\mathrm{D}$ is average metal particle size $(\mu \mathrm{m})$ and $\mathrm{P}$ is water pressure $(\mathrm{MPa})$. The above equations were based on the result of the atomization of $\mathrm{Fe}-\mathrm{Ni}$ alloy, carbon steel, high-speed tool steel, and pure nikel. It also shows that higher pressure water was needed to produce finer resolution powder. 


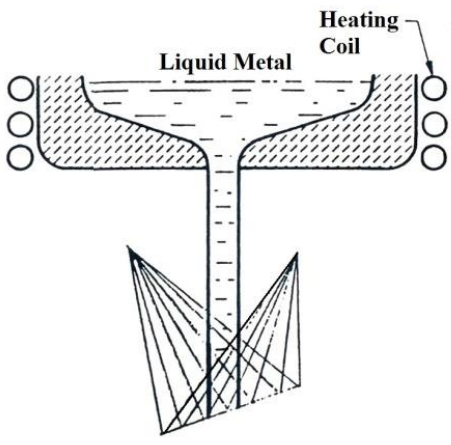

(a)



(b)

Fig. 2. Type of water jet in water atomization process (a) V-jet and (b) cone jet [10].

Grandzol (1973) showed a simple relationship between the average particle size, $\mathrm{D}(\mu \mathrm{m})$, and the water velocity, $\mathrm{V}_{\mathrm{w}}(\mathrm{m} / \mathrm{s})$, which later modified by Grandzol and Tallmadge [12] to yield.

$$
D=S /\left(V_{w} \sin \alpha\right)
$$

where $\alpha$ is the angle between the water jet axis and the molten metal stream axis and $S$ is the normal velocity component.

In the previous studies, Yenwiset S. and Yenwiset, T. (2010) reported that using double V-jet water atomization made resolution metal powder finer than using cone water nozzle at the same water pressure [13] and in 2011 reported that higher water pressure and higher metal's superheat temperature made more yield of finer particles [14].

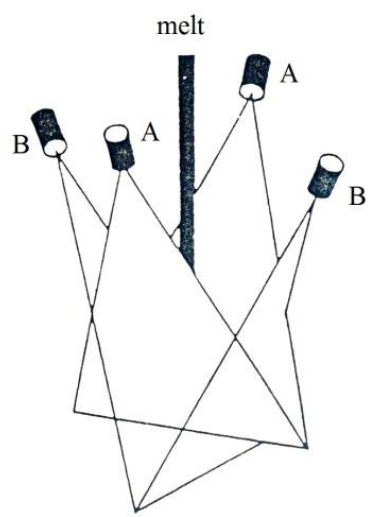

A - main nozzles

B - auxiliary nozzle

Fig. 3. Schematic of double V-jet water atomization [15].

M. Pasupathy et al. (2011) studied about the effect of the atomizer geometrical configuration on particle size and shape of atomized powder and the results showed that when impact angle is increased and/or water jet length reduced, the obtained powder becomes finer and more irregular [16].

From the information above, it is clear that to produce very fine metal powder, the process requires much energy for very high water pressure and very high superheat temperature of metal. However, besides the above variables, the shape of the molten metal stream may affect the production of metal powders as well.

The experiment was set by producing copper powder using the different tundish nozzle's shape and size while the other process condition were same. The objective of this study is to find out whether the shape of molten metal stream can affect the particle size and size distribution. 


\section{Experimental}

\subsection{Material}

Material employed for this study was copper with 99\% purity.

\subsection{Variable}

Two shape of tundish nozzle's orifice were used in the experiments to make round sectional metal stream and flat rectangular sectional metal stream.

To emphasize at the effect of metal stream shape, the metal flow rate from the two different shapes of nozzle orifice are controlled to nearly equal by using the similar size of cross-sectional area to avoid the effect of different metal flow rate.

However, three different sizes for each shape were applied to the experiment to validate whether the metal stream shape affecting on the particle size of powder.
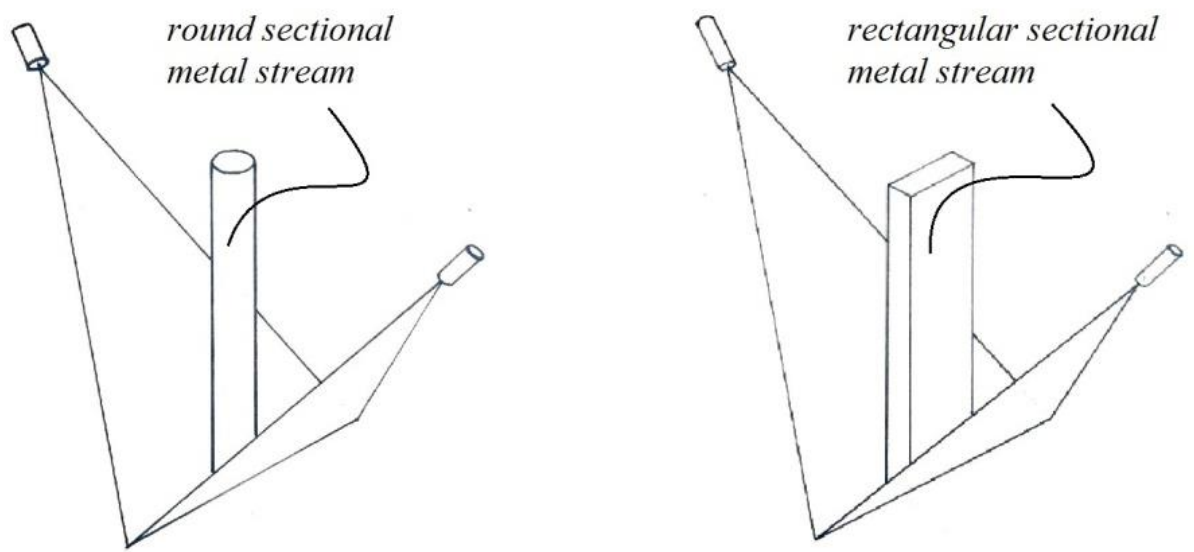

Fig. 4. Metal streams from round sectional orifice and rectangular sectional orifice.

Table 1. Tundish nozzle orifice's shapes and sizes used in the experiment.

Round sectional orifice

Rectangular sectional orifice

\begin{tabular}{c}
$\begin{array}{c}\text { Approximate } \\
\text { metal flow } \\
\text { rate }\end{array}$ \\
\hline \\
\\
\\
\hline$\sim 13 \mathrm{~kg} / \mathrm{min}$ \\
$\sim 19 \mathrm{~kg} / \mathrm{min}$ \\
$\sim 26 \mathrm{~kg} / \mathrm{min}$ \\
\hline
\end{tabular}

\subsection{Operating Conditions in Water Atomization}

The water atomization process used double V-jet nozzle (see Fig. 3) with the conditions and machine configurations as shown in Table 2 and Fig. 5. The fixed values are chosen because they are the best condition for the machine which provided the highest yield of fine particle from the previous studies [13, 14]. 
Table 2. Water atomization process conditions.

\begin{tabular}{lr}
\hline Parameter & Value \\
\hline Metal superheated temperature & $150^{\circ} \mathrm{C}$ \\
Water Pressure (before nozzle) & $11 \mathrm{MPa}$ \\
Water Flow Rate (per each nozzle) & $20 \mathrm{~L} / \mathrm{min}$ \\
Total Water Flow Rate (all 4 nozzles) & $80 \mathrm{~L} / \mathrm{min}$ \\
Spread Fan Angle of Water Jet & $20^{\circ}$ \\
Width of Water Intersection (w) & $100 \mathrm{~mm}$ \\
Main V-Jet Angle $(\gamma)$ & $80^{\circ}$ \\
Auxiliary V-Jet Angle & $70^{\circ}$ \\
Metal Stream Falling Distance $(\mathrm{h})$ & $300 \mathrm{~mm}$ \\
\hline
\end{tabular}

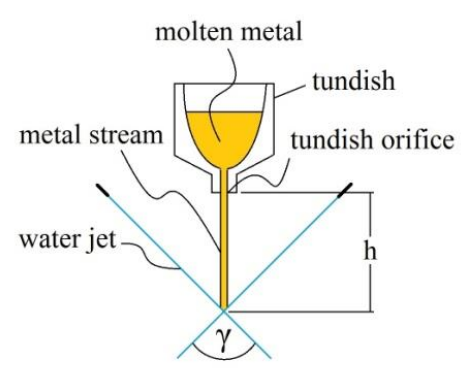

(a) Front Section View



(b) Isometric View

Fig. 5. Water atomization machine's configuration: (a) front sectional view and (b) isometric view.

\subsection{Experimental Procedure}

From Table 1, six different tundish orifices were applied into the experiment. Three replicates were produce with each orifice and 15 kilogram of copper was produced for each batch. Therefore, a total 45 kilogram of copper was produced for each orifice.

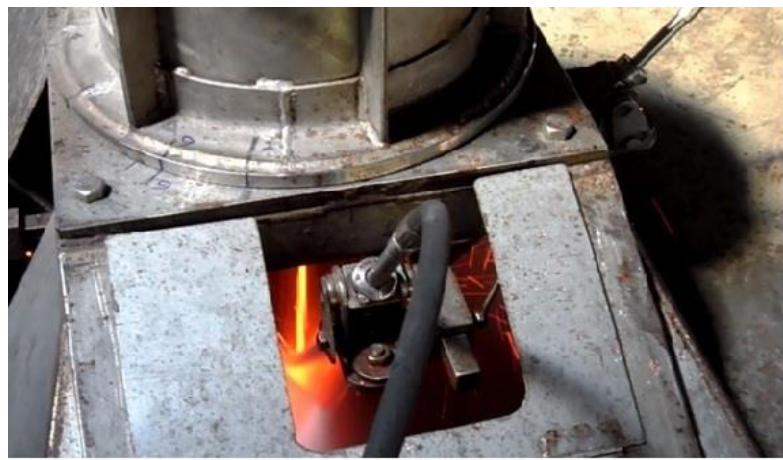

(a)

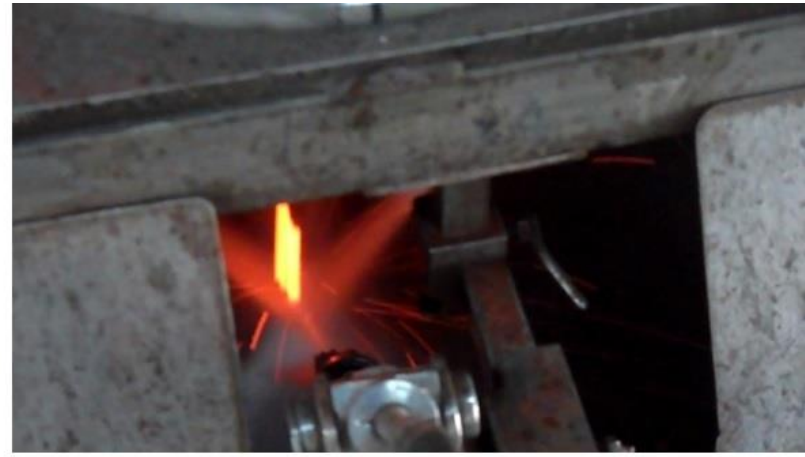

(b)

Fig. 6. Water atomization process: (a) using round orifice; and (b) using rectangular orifice.

\section{Results and Discussions}

Sieve analysis using the standard wire cloth sieves (ASTM E11) is the most widely used method of determining particle size distribution of metal powder [17]. The copper powder produced from each orifices were taken to investigate their particle size distribution by sieving. The sieve analysis results (average from 3 replicates) are shown from Table 3 to Table 5. The S-curves created from the result are shown from Fig. 7 to Fig. 9 
Table 3. Sieved size distribution of copper powder produced at $13 \mathrm{~kg} / \mathrm{min}$ metal flow rate.

\begin{tabular}{|c|c|c|c|c|c|}
\hline \multirow{2}{*}{$\begin{array}{c}\text { ASTM-E11 } \\
\text { Sieve } \\
\text { Designation } \\
\text { No. }\end{array}$} & \multirow{2}{*}{$\begin{array}{c}\text { Standard } \\
\text { Size } \\
(\mu \mathrm{m})\end{array}$} & \multicolumn{2}{|c|}{$\begin{array}{l}\text { Produced with A1 } \\
\text { ( } \varnothing 5 \mathrm{~mm} \text { orifice) }\end{array}$} & \multicolumn{2}{|c|}{$\begin{array}{c}\text { Produced with B1 } \\
(3 \mathrm{~mm} \times 6.5 \mathrm{~mm} \text { orifice })\end{array}$} \\
\hline & & $\begin{array}{c}\% \\
\text { Retained }\end{array}$ & $\begin{array}{c}\% \\
\text { Cumulative } \\
\text { Passing }\end{array}$ & $\begin{array}{c}\% \\
\text { Retained }\end{array}$ & $\begin{array}{c}\% \\
\text { Cumulative } \\
\text { Passing }\end{array}$ \\
\hline 100 & 150 & 6.8 & 93.2 & 4.7 & 95.3 \\
\hline 120 & 125 & 0.9 & 92.3 & 1.1 & 94.2 \\
\hline 140 & 106 & 3.6 & 88.7 & 2.6 & 91.6 \\
\hline 170 & 90 & 4.1 & 84.6 & 5.2 & 86.4 \\
\hline 200 & 75 & 9.3 & 75.3 & 6.8 & 79.6 \\
\hline 230 & 63 & 8.4 & 66.9 & 9.2 & 70.4 \\
\hline 270 & 53 & 13.1 & 53.8 & 11.8 & 58.6 \\
\hline 325 & 45 & 12.6 & 41.2 & 13.4 & 45.2 \\
\hline 400 & 38 & 16.7 & 24.5 & 16.1 & 29.1 \\
\hline 450 & 32 & 13.3 & 11.2 & 15.3 & 13.8 \\
\hline 500 & 25 & 7.0 & 4.2 & 8.5 & 5.3 \\
\hline pan & 0 & 4.2 & - & 5.3 & - \\
\hline
\end{tabular}

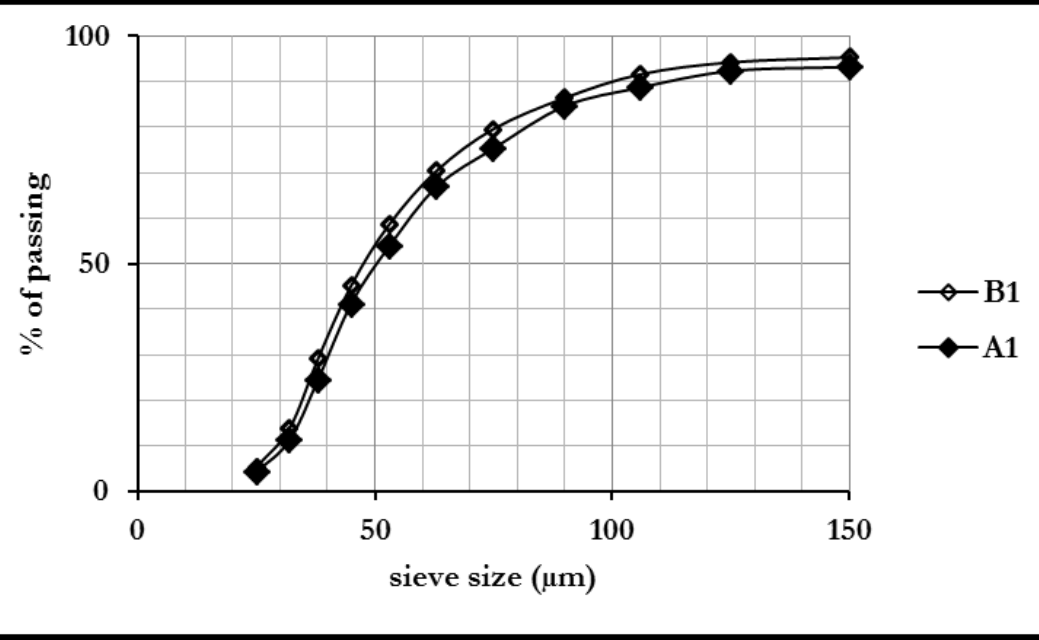

Fig. 7. Cumulative percentage of undersize of copper powder produced with metal flow rate $\sim 13$ $\mathrm{kg} / \mathrm{min}$.

Table 4. Sieved size distribution of copper powder produced at $19 \mathrm{~kg} / \mathrm{min}$ metal flow rate.

\begin{tabular}{|c|c|c|c|c|c|}
\hline \multirow{2}{*}{$\begin{array}{c}\text { ASTM-E11 } \\
\text { Sieve } \\
\text { Designation } \\
\text { No. }\end{array}$} & \multirow{2}{*}{$\begin{array}{c}\text { Standard } \\
\text { Size } \\
(\mu \mathrm{m})\end{array}$} & \multicolumn{2}{|c|}{$\begin{array}{l}\text { Produced with A2 } \\
\text { ( } \varnothing 6 \mathrm{~mm} \text { orifice) }\end{array}$} & \multicolumn{2}{|c|}{$\begin{array}{c}\text { Produced with B2 } \\
(3 \mathrm{~mm} \times 9.5 \mathrm{~mm} \text { orifice })\end{array}$} \\
\hline & & $\begin{array}{c}\% \\
\text { Retained }\end{array}$ & $\begin{array}{c}\% \\
\text { Cumulative } \\
\text { Passing }\end{array}$ & $\begin{array}{c}\% \\
\text { Retained }\end{array}$ & $\begin{array}{c}\% \\
\text { Cumulative } \\
\text { Passing }\end{array}$ \\
\hline 100 & 150 & 8.6 & 91.4 & 6.9 & 93.1 \\
\hline 120 & 125 & 3.4 & 88.0 & 1.9 & 91.2 \\
\hline 140 & 106 & 5.9 & 82.1 & 3.6 & 87.6 \\
\hline 170 & 90 & 6.8 & 75.3 & 5.2 & 82.4 \\
\hline 200 & 75 & 7.5 & 67.8 & 9.3 & 73.1 \\
\hline 230 & 63 & 9.5 & 58.3 & 9.6 & 63.5 \\
\hline 270 & 53 & 15.7 & 42.6 & 13.9 & 49.6 \\
\hline 325 & 45 & 16.9 & 25.7 & 15.3 & 34.3 \\
\hline 400 & 38 & 9.4 & 16.3 & 14.1 & 20.2 \\
\hline 450 & 32 & 8.7 & 7.6 & 10.8 & 9.4 \\
\hline 500 & 25 & 4.8 & 2.8 & 6.2 & 3.2 \\
\hline pan & 0 & 2.8 & - & 3.2 & - \\
\hline
\end{tabular}




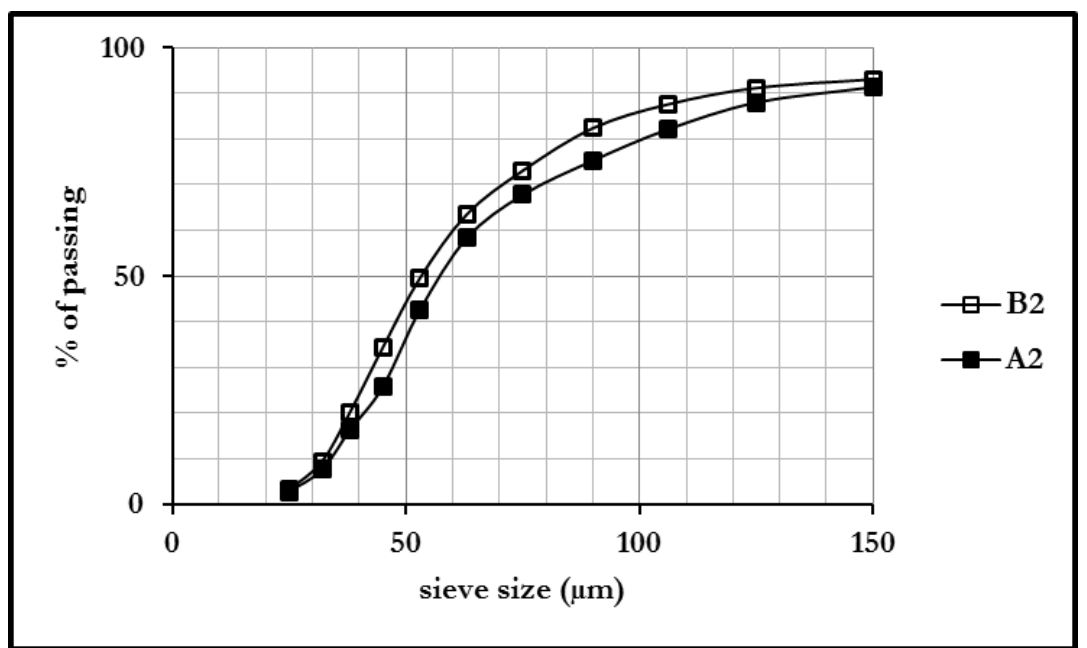

Fig. 8. Cumulative percentage of undersize of copper powder produced with metal flow rate $\sim 19$ $\mathrm{kg} / \mathrm{min}$.

Table 5. Sieved size distribution of copper powder produced at $26 \mathrm{~kg} / \mathrm{min}$ metal flow rate.

\begin{tabular}{|c|c|c|c|c|c|}
\hline \multirow{2}{*}{$\begin{array}{c}\text { ASTM-E11 } \\
\text { Sieve } \\
\text { Designation } \\
\text { No. }\end{array}$} & \multirow{2}{*}{$\begin{array}{l}\text { Standard } \\
\text { Size } \\
(\mu \mathrm{m})\end{array}$} & \multicolumn{2}{|c|}{$\begin{array}{l}\text { Produced with A3 } \\
\text { ( } \varnothing 6 \mathrm{~mm} \text { orifice) }\end{array}$} & \multicolumn{2}{|c|}{$\begin{array}{c}\text { Produced with B3 } \\
(3 \mathrm{~mm} \times 6.5 \mathrm{~mm} \text { orifice })\end{array}$} \\
\hline & & $\begin{array}{c}\% \\
\text { Retained }\end{array}$ & $\begin{array}{c}\% \\
\text { Cumulative } \\
\text { Passing }\end{array}$ & $\begin{array}{c}\% \\
\text { Retained }\end{array}$ & $\begin{array}{c}\% \\
\text { Cumulative } \\
\text { Passing }\end{array}$ \\
\hline 100 & 150 & 9.9 & 90.1 & 8.2 & 91.8 \\
\hline 120 & 125 & 5.7 & 84.4 & 3.5 & 88.3 \\
\hline 140 & 106 & 6.7 & 77.7 & 5.1 & 83.2 \\
\hline 170 & 90 & 6.2 & 71.5 & 5.7 & 77.5 \\
\hline 200 & 75 & 8.3 & 63.2 & 10.7 & 66.8 \\
\hline 230 & 63 & 12.5 & 50.7 & 10.5 & 56.3 \\
\hline 270 & 53 & 15.2 & 35.5 & 15.7 & 40.6 \\
\hline 325 & 45 & 15.2 & 20.3 & 16.7 & 23.9 \\
\hline 400 & 38 & 8.7 & 11.6 & 10.5 & 13.4 \\
\hline 450 & 32 & 6.8 & 4.8 & 8.2 & 5.2 \\
\hline 500 & 25 & 4.1 & 0.7 & 3.9 & 1.3 \\
\hline pan & 0 & 0.7 & - & 1.3 & - \\
\hline
\end{tabular}

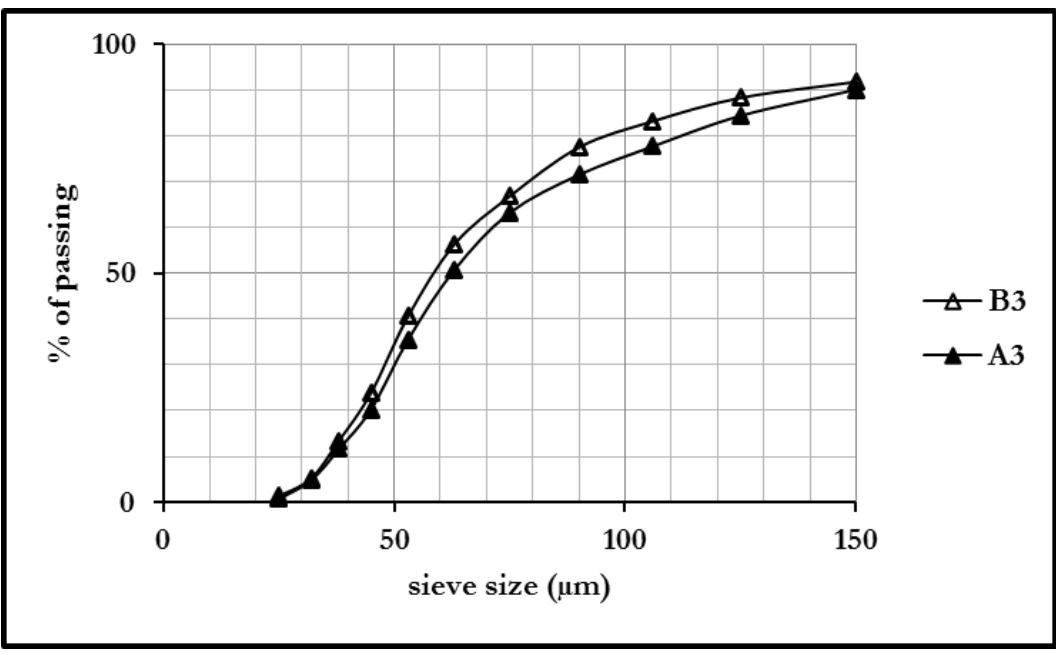

Fig. 9. Cumulative percentage of undersize of copper powder produced with metal flow rate $\sim 26$ $\mathrm{kg} / \mathrm{min}$. 
Table 6. Comparison of the yield of the production with each orifice.

\begin{tabular}{|c|c|c|c|c|c|c|}
\hline \multirow{5}{*}{$\begin{array}{l}\text { Size } \\
(\mu \mathrm{m})\end{array}$} & \multicolumn{6}{|c|}{ Cumulative percentage of passing ( $\%$ yield of undersize) } \\
\hline & \multicolumn{2}{|c|}{ orifice $13 \mathrm{~kg} / \mathrm{min}$} & \multicolumn{2}{|c|}{ orifice $16 \mathrm{~kg} / \mathrm{min}$} & \multicolumn{2}{|c|}{ orifice $26 \mathrm{~kg} / \mathrm{min}$} \\
\hline & A1 & B1 & A2 & $\mathbf{B} 2$ & A3 & B3 \\
\hline & & $3 \mathrm{~mm}$ & & $3 \mathrm{~mm}$ & & $3 \mathrm{~mm}$ \\
\hline & $\varnothing 5 \mathrm{~mm}$ & x $6.5 \mathrm{~mm}$ & $\varnothing 6 \mathrm{~mm}$ & x $9.5 \mathrm{~mm}$ & $\varnothing 7 \mathrm{~mm}$ & x $12 \mathrm{~mm}$ \\
\hline 150 & 93.2 & 95.3 & 91.4 & 93.1 & 90.1 & 91.8 \\
\hline 125 & 92.3 & 94.2 & 88.0 & 91.2 & 84.4 & 88.3 \\
\hline 106 & 88.7 & 91.6 & 82.1 & 87.6 & 77.7 & 83.2 \\
\hline 90 & 84.6 & 86.4 & 75.3 & 82.4 & 71.5 & 77.5 \\
\hline 75 & 75.3 & 79.6 & 67.8 & 73.1 & 63.2 & 66.8 \\
\hline 63 & 66.9 & 70.4 & 58.3 & 63.5 & 50.7 & 56.3 \\
\hline 53 & 53.8 & 58.6 & 42.6 & 49.6 & 35.5 & 40.6 \\
\hline 45 & 41.2 & 45.2 & 25.7 & 34.3 & 20.3 & 23.9 \\
\hline 38 & 24.5 & 29.1 & 16.3 & 20.2 & 11.6 & 13.4 \\
\hline 32 & 11.2 & 13.8 & 7.6 & 9.4 & 4.8 & 5.2 \\
\hline 25 & 4.2 & 5.3 & 2.8 & 3.2 & 0.7 & 1.3 \\
\hline 0 & - & - & - & - & - & - \\
\hline
\end{tabular}

The most widely used indicator to describe particle size distribution are D-values. The D10, D50 and D90 are commonly used to represent the midpoint and range of the particle size [18, 19]. Particle size distribution have been traditional calculated based on sieve analysis results, creating S-curve of cumulative percentage against sieve size, and find the intercepts for $10 \%, 50 \%$ and $90 \%$ mass. They give an indication of the fine (D10), coarse (D90) and median (D50) particle size. The most common values used for measuring the distribution width is the range which calculated by equations below [20]:

$$
\text { Particle Size Distribution Range }=\text { D90 }- \text { D10 }
$$

The D-values measure form the S-curves are shown in Table 7 and Fig. 10.

Table 7. The D-values and the Ranges of distribution.

\begin{tabular}{clcccc}
\hline \multirow{2}{*}{ Metal flow rate } & \multicolumn{1}{c}{ Produced with } & $\begin{array}{c}\text { D10 } \\
(\mu \mathrm{m})\end{array}$ & $\begin{array}{c}\text { D50 } \\
(\boldsymbol{\mu m})\end{array}$ & $\begin{array}{c}\text { D90 } \\
(\boldsymbol{\mu m})\end{array}$ & $\begin{array}{c}\text { Range } \\
(\mathbf{D} 90-\mathbf{D} 10)\end{array}$ \\
\hline \multirow{2}{*}{$13 \mathrm{~kg} / \mathrm{min}$} & A1 $(\varnothing 5 \mathrm{~mm})$ & 32 & 51 & 112 & 80 \\
& B1 $(3 \mathrm{~mm} \times 6.5 \mathrm{~mm})$ & 29 & 48 & 100 & 71 \\
\multirow{2}{*}{$19 \mathrm{~kg} / \mathrm{min}$} & A2 $(\varnothing 6 \mathrm{~mm})$ & 34 & 58 & 140 & 106 \\
& B2 $(3 \mathrm{~mm} \times 9.5 \mathrm{~mm})$ & 32 & 54 & 120 & 88 \\
\multirow{2}{*}{$26 \mathrm{~kg} / \mathrm{min}$} & A3 $(\varnothing 7 \mathrm{~mm})$ & 38 & 62 & 150 & 112 \\
& B3 $(3 \mathrm{~mm} \times 12 \mathrm{~mm})$ & 36 & 58 & 135 & 99 \\
\hline
\end{tabular}




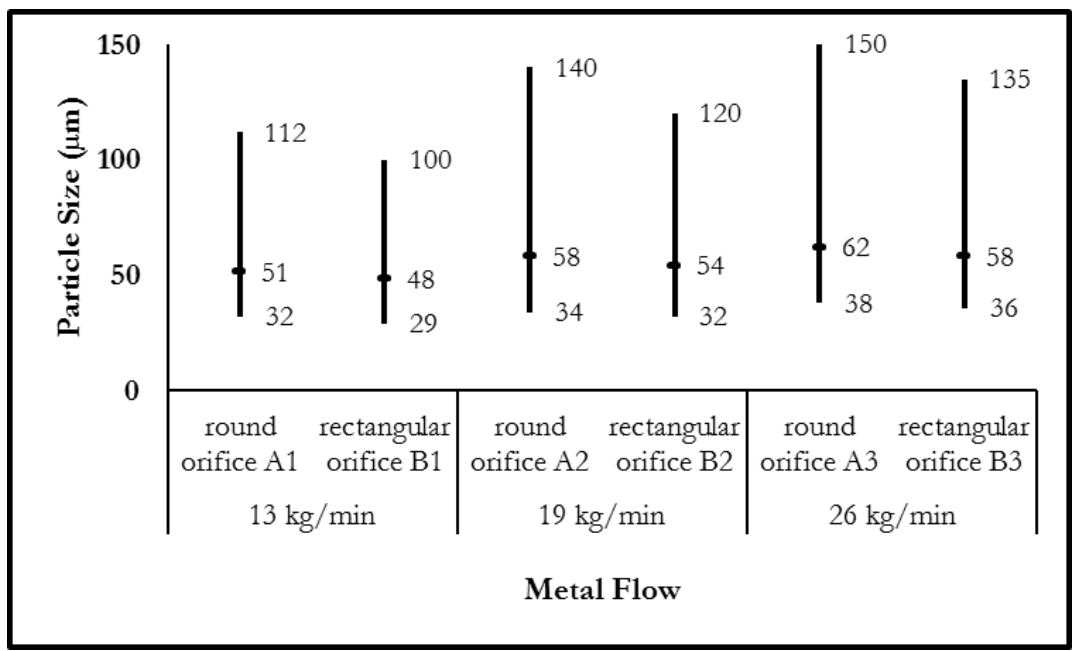

Fig. 10. Particle size distribution range from D10 to D90 with D50.

The results show that at the same metal flow rate, production with wide-thin metal stream from rectangular orifices provided narrower range of particle size distribution and smaller D50 than production with round orifices. It might explain that metal stream from rectangular orifices has wider flat area which face directly to the water jets and thinner stream which made easier to be atomized. While the outer curve of round section metal stream will not impinge perpendicular to water jets and more thickness in the middle make it be less atomized (see Fig. 11).

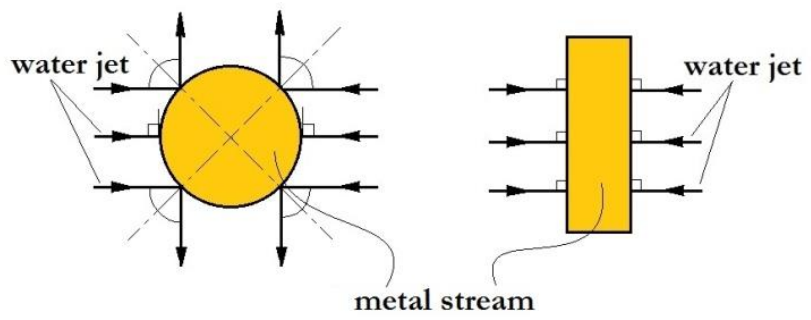

Fig. 11. Impinge of water jet and metal stream comparison between round and rectangular cross section metal stream.

From the yields, D50 and ranges of distribution which shown in Table 6, 7 and Fig. 10, it could be said that production with the thin flat metal stream can produce more yield of finer resolution powder at the same production rate. And because of narrower range of size distribution we can obtain more yield of any specific particle size.. On the other hand, while compare the results of A1 $(13 \mathrm{~kg} / \mathrm{min})$ with B2 $(19 \mathrm{~kg} / \mathrm{min})$ or A2 $(19 \mathrm{~kg} / \mathrm{min})$ with B3 $(26 \mathrm{~kg} / \mathrm{min})$ their D-values and range are very similar. It could be said that the production of flat metal stream can produce as similar resolution as the production of round section stream but higher production rate.

\section{Conclusions}

The results indicated that the shape of molten metal stream can affect the resolution of atomized metal powder significantly. At the equally molten metal's flow rates, the production with the flat metal stream from rectangular section orifices can make smaller size of D10, D50 and D90, narrower range of size distribution than the production using round section orifices.

The assumption for describing the result is the metal stream which flows from rectangular orifice is wider and thinner, has larger flat surface area faced to the water jets which made more chance to be collided directly by water jets and split into smaller particle. While the metal stream which flows from round orifice is thicker stream which is more difficult to collide to the center of the stream. 
For the same shape of molten metal orifice, producing with the smaller size of orifice or lower metal flow rate made D10, D50 and D90 tend to become smaller. That means increasing of the ratio of water/metal flow rate will made higher yield of finer particle.

At the same process conditions, using rectangular cross section orifice made higher yield of finer resolution powder than producing with the circular cross section orifice. That means the process consumed the same amount of energy but produced finer powder.

\section{References}

[1] A. Bose, "Introduction," in Advanced in particulate Materials. MA: Butterworth-Heinemann, 1995, pp. 1-5.

[2] A. Bose, "Melt atomization," in Advanced in particulate Materials. MA: Butterworth-Heinemann, 1995, pp. 86.

[3] J. J. Dunkly, "Gas atomization a review of the current state of the art," Advances in Powder Metallurgy \& Particulate Materials, vol. 1, pp. 55-66, 1999.

[4] R. J. Grandzol, "Water atomization of 4620 steel and other metals", Ph.D. Thesis, Dept. Chem. Eng., Drexel University, Philadephia, PA, 1973.

[5] R. W. Stevenson, "P/M copper-base alloys," in ASM Handbook, Powder Metallurgy, 9th ed. Ohio, ASM, 1984, vol. 7, pp. 733-740.

[6] E. Klar and J. W. Fesko, "Gas and water atomization," in ASM Handbook, Powder Metallurgy, 9th ed. Ohio, ASM, 1984, vol. 7, pp. 25-39.

[7] E. Klar, "Production of copper powder by atomization," in ASM Handbook, Powder Metallurgy, 9th ed. Ohio, ASM, 1984, vol. 7, pp. 116-118.

[8] P. W. Taubenblat, "Importance of copper in powder metallurgy," Int. J. Powder Met. and Powder Tech., vol. 10, no. 2, pp. 169, Jul, 1974.

[9] A. Kimura, K. Nakabayashi, and T. Shimura, "Powder production at pacific metals," Metal Powder Report, vol. 45, no. 2, pp. 106-110, Feb, 1990.

[10] R. M. German, Powder Metallurgy Science. Princeton, NJ: MPIF, 1984, pp. 80.

[11] Y. Seki, S. Okamoto, H. Takisawa, and N. Kawai, "Effect of atomization variables on powder characteristics in the high-pressured water atomization process," Metal Powder Report, vol. 45, no. 1, pp. 38-40, Jan, 1990.

[12] R. J. Grandzol and J. A. Tallmadge, "Effect of jet angle on water atomization," Int. J. Powder Met. and Powder Tech., vol. 11, pp. 103-114, 1975.

[13] S. Yenwiset and T. Yenwiset, "Design and construction of water atomizer for making metal powder," Journal of Metals, Materials and Minerals, vol. 21, no. 1, pp. 75-81, Jun, 2011.

[14] S. Yenwiset and T. Yenwiset, "Study on key variables that influence the effectiveness of water atomization process," in Proceedings of EURO PM 2011 Powder Metallurgy Congress and Exbibition, Barcelona, Spain, Sep., 2011, vol. 2, pp. 43-48.

[15] J. M. Vetter, G. Gross, and H. W. Bergmann, "Production of metal powders by atomizing their melts with liquid gases," Metal Powder Report, vol. 45, no. 2, pp. 100-104, 1990.

[16] M. Pasupathy, J. M. Martin, I. Iturriza, and F. Castro, "Effect of the atomizer geometrical configuration on the particle size and shape of water atomized powders," in Proceedings of EURO PM 2011 Powder Metallurgy Congress and Exbibition, Barcelona, Spain, Sep., 2011, vol. 2, pp. 9-14.

[17] W. J. Ullrish, "Sieve analysis" in ASM Handbook, Powder Metallurgy, vol. 7, 9th ed. Ohio: ASM, 1984, pp. 214-216.

[18] B. B. Weiner. (2011). What is a Continuous Particle Size Distribution. Brookhaven Instruments. [Online]. Available: https://www.brookhaveninstruments.com/pdf/theory/What is a Continuous Particle Size Distribution.pdf

[19] B. B. Weiner. (2011). What is a Discrete Particle Size Distribution. Brookhaven Instruments. [Online]. Available: http://www.brookhaveninstruments.com/pdf/theory/What is a Discrete Particle Size Distribution.pdf

[20] L. Neumann, E. T. White, and T. Howes, "What does a mean size mean?," in 2003 AIChE Presentation at Session 39 Characterization of Engineered Particles, San Francisco, CA, Nov. 2003, pp. 16-21. 